\title{
Doenças pulmonares obstrutivas crônicas
}

\author{
RogéRIO Lopes Rufino ALVES ${ }^{1}$
}

\section{Comentários dos trabalhos de DPOC APRESENTADOS NA ATS}

A doença pulmonar obstrutiva crônica é a quarta causa mais comum de óbitos, nos Estados U nidos da A mérica, com 85.544 casos relacionados em 1991. A comete aproximadamente 30 a 35 milhões de pessoas, sendo que a metade somente apresenta alterações na espirometria, com ausência de sintomatologia(1).

No período de 1981 a 1991, houve aumento de 32,9\% da taxa de mortalidade da DPOC, apesar do declínio deste índice com relação a outras doenças, como o infarto agudo do miocárdio e 0 infarto cerebral(2).

Este artigo tem como objetivo tecer comentários sobre os trabalhos brasileiros, que foram encaminhados e expostos no Congresso da Sociedade Torácica A mericana, sobre este tema.

O primeiro trabalho a ser comentado é o de Martinez e col., Reliability of dyspnea scales in the assessment of literate and illiterate patients with chronic obstructive pulmonary disease, que, com inteligência, tenta demonstrar a dificuldade diária do atendimento médico no Brasil, onde uma parcela da população é analfabeta ou com pouco nível de escolaridade, de acordo com os critérios da Unicef. Este grupo de 30 pacientes foi comparado com outro, com 57 pacientes, este com algum grau de escolaridade. Todos apresentavam limitação do fluxo aéreo diagnosticado pela espirometria e realizavam medidas da dispnéia através de diferentes escalas (analógica visual, escala de taxa numérica, escala de Borg e índice de dispnéia basal) antes e após a prova de função respiratória. Os resultados demonstraram que houve ótima correlação de cada escala de dispnéia antes e após a espirometria com os valores obtidos. A melhor correlação foi alcançada através da utilização do índice de dispnéia basal. Ficou demonstrado, ainda, que não havia diferença na medida de dispnéia entre os grupos de analfabetos e alfabetizados. Neste trabalho, verifica-se que as várias escalas de dispnéia testadas apresentaram boa correlação; isto é importante, porque um dos objetivos no tratamento da DPOC é a prevenção e a redução da dispnéia e, dessa forma, sua medida é fundamental. O s questionários usados no acompanhamento da evolução da DPOC já sabidamente apresen-

1. Presidente da Comissão de Doenças Pulmonares O bstrutivas C rônicas (DPOC) da SBPT; Professor Assistente de Pneumologia da Faculdade de Ciências Médicas da Universidade do Estado do Rio de J aneiro. E-mail: ruffino@domain. com.br tam correlação com a ventilação-minuto e o consumo de oxigênio ${ }^{(3)}$. Assim, a normatização destes utensílios clínicos deve levar em consideração vários fatores objetivos e subjetivos que podem inferir na baixa reprodutibilidade do método: desde 0 técnico que apresenta o questionário com linguagem diferente da usada comumente pelo paciente, até a interpretação deste achado. Nestes casos, a população com pouca ou nenhuma escolaridade poderia apresentar valores sub ou superestimados, o que não foi verificado por este trabalho.

O objetivo do trabalho de O liveira e col., Effects of continuous positive airway pressure in pulmonary rehabilitation in patients with chronic obstructive pulmonary disease, foi estudar a utilização da pressão positiva contínua das vias aéreas (CPAP), com $5 \mathrm{~cm} \mathrm{H}_{2} \mathrm{O}$, associada à reabilitação convencional, na redução do trabalho respiratório e da dispnéia. Dois grupos foram feitos, ambos com quatro pacientes. 0 primeiro foi tratado com reabilitação e CPAP e outro, somente com reabilitação. O s efeitos desta abordagem terapêutica foram analisados após 36 sessões de reabilitação, perfazendo 12 semanas de acompanhamento, com os seguintes métodos: teste da caminhada dos seis minutos, espirometria, medida da pressão inspiratória máxima e avaliação do grau de dispnéia através da escala de Borg. No grupo que utilizou os dois métodos, houve melhora dos parâmetros analisados e os autores concluíram que o uso de CPAP pode ser de ajuda no incremento da endurance. Esses dados são corroborados por trabalhos já publicados, embora outros autores tenham observado resultados pouco promissores após a utilização de CPAP. No estudo de Elliot e col.(4) em seis pacientes tratados com CPAP nasal noturno por seis meses, houve melhora da troca gasosa; todavia, no estudo de Strumpf e col..$^{(5)}$ feito em sete pacientes não houve alteração da troca gasosa. Em outro trabalho de Lin e col. ${ }^{(6)}$ com 12 pacientes DPOC hipercápnicos que apresentavam dessaturação noturna, os parâmetros propostos para análise (espirometria, pressão inspiratória máxima, volume-minuto e a troca gasosa) não apresentaram melhora em nenhum dos grupos estudados: somente CPAP, somente oxigênio e com as duas modalidades terapêuticas. O utro estudo, multicêntrico, europeu(7), com 104 pacientes com DPOC, comparando a utilização CPAP com oxigênio e somente oxigênio, demonstra tendência maior de sobrevida para o grupo que usou CPAP. Deste modo, o estudo de O liveira e col. apresenta dados objetivos de que a utilização de CPAP contribui de maneira favorável para a melhora clínica do paciente com DPOC. A utilização 
rotineira de CPAP no tratamento de pacientes com DPOC ainda não é consensual na literatura, devido aos trabalhos conflitantes existentes e da dificuldade de estabelecer critérios clínicos e funcionais para incluir o CPAP como modalidade terapêutica ambulatorial.

0 trabalho de Machado e col., Long-term oxygen therapy-prospective 2-year study using guidelines adapted to Brazilian public health system reality: population, characteristics, benefits and mortality rate, foi realizado em 129 pacientes no perío do de outubro de 1996 a outubro de 1998. Neste estudo, o perfil dos pacientes que necessitavam da suplementação de oxigênio era de homens de 70 anos, exfumantes, caucasianos, hipoxêmicos $(55 \mathrm{mmH} \mathrm{g})$, com $\mathrm{VEF}_{1}$ de $1 \mathrm{~L}$ e hipertensão arterial pulmonar, e que, durante 0 tratamento com oxigênio, apresentaram diminuição da freqüência de hospitalização e da taxa de mortalidade. Os estudos randomizados e controlados do Nocturnal Oxygen Therapy Trial and Medical Research Council(8,9) demonstraram que a utilização de oxigênio em pacientes hipoxêmicos altera a sobrevida. A melhora foi diretamente relacionada com o número de horas diárias de uso de oxigênio. Quanto maior o número de horas (um grupo com média diária de 19 horas e outro, com 12 horas), maior é a sobrevida. Contudo, o uso do oxigênio nos pacientes hipoxêmicos não melhora somente a sobrevida, há também aumento da endurance e da distância percorrida no teste da caminhada, diminuição da ventilação-minuto ${ }^{(10)}$, da sensação de dispnéia, do trabalho respiratório, da pressão da artéria pulmonar, da policitemia e de arritmias cardíacas ${ }^{(11)}$, com melhora da qualidade do sono e das funções do sistema nervoso central(12). 0 objetivo da terapia com oxigênio domiciliar é manter $\mathrm{P} \mathrm{PaO}_{2}$ maior que $60 \mathrm{mmHg}$ ou a saturação de oxigênio acima de $90 \%$, sem aumentos excessivos da $\mathrm{PaCO}_{2}$. Este trabalho é de grande importância, porque demonstra quais são as principais doenças no Brasil que necessitarão de oxigênio domiciliar e corrobora várias informações obtidas de estudos estrangeiros.

No trabalho de Lin e col., Association between air pollution and cardiovascular admissions in São Paulo, realizado no período de janeiro de 1994 a dezembro de 1995, foram feitas correlações diárias entre o número de pacientes admitidos no Instituto do Coração, com medidas diárias de $\mathrm{CO}$ (monóxido de carbono), $\mathrm{SO}_{2}$ (dióxido sulfúrico), $\mathrm{PM}_{10}$ (partículas menores que $10 \mathrm{~mm}$ de diâmetro aerodinâmico) e do ozônio realizadas pela Cetesb (A gência de Controle de Poluição Atmosférica do Estado de São Paulo) e das variações climáticas observadas pelo Instituto de Astronomia e Geofísica da Universidade de São Paulo. Dessas variáveis, o $\mathrm{CO}$ foi a que apresentou maior associação com o número de admissões cardiovasculares. Além disso, níveis médios de 5,2 ppm estavam relacionados com aumentos de $6 \%$ nos casos de angina e infarto do miocárdio. 0 monóxido de carbono é um gás invisível formado pela combustão incompleta de materiais orgânicos e combustíveis. Classicamente, a sua fonte mais conhecida é a combustão da gasolina e do diesel dos veículos e fábricas. Dependendo da região e do tráfego de carros, o CO pode alcançar níveis elevados. O CO inalado se acopla à hemoglobina com alta afinidade, formando a carboxiemoglobina ( $\mathrm{COH}$ b). Este complexo é muito estável, com meia-vida variável de 2,5 a 4 horas. Pessoas com doença cardiovascular possuem maior risco de apresentar sintomas, quando expostos ao $\mathrm{CO}$. Se a concentração sérica de $\mathrm{COHb}$ for maior que $6 \%$, há maior incidência de arritmia cardía$\mathrm{ca}^{(13)}$. N este estudo fica demonstrado que o controle atmosférico é extremamente necessário tanto para prevenção de doenças pulmonares, como cardiovasculares.

No trabalho de Oliveira, Gastaldi e J ardim, The ciliary transportation of the sputum of COPD patients is slow both on the frog palate and on the bovine trachea, foi estudado um novo método de avaliação do transporte de muco em traquéia bovina. Este método pode fazer previsões diferentes quando comparado com o método de transporte ciliar do muco em palatos de sapos. Expectoração de oito pacientes com DPOC foi colocada no palato de sapos e em traquéias bovinas. Foram feitas cinco medidas em 36 dias. A ssim, verificou-se que o transporte da secreção da DPOC é retardado nos dois métodos testados, porém, mais lento no palato de sapos e, ainda, que este apresenta menor variabilidade como método para medir o transporte ciliar de DPOC; contudo, na formulação de previsões, não são diferentes. No tipo bronquítico da DPOC, no qual existem alterações fisiopatológicas bem conhecidas, como o aumento da massa das glândulas submucosas, aumento do número e também da distribuição das células caliciformes (normalmente presentes na superfície epitelial dos brônquios principais até os bronquíolos proximais, diminuindo em quantidade e volume na direção da periferia pulmonar), as alterações das relações do conteúdo e da qualidade do muco poderiam ser relacionadas com as mudanças perpetuadoras da doença ${ }^{(14)}$.

No trabalho de Oliveira, Saldiva e J ardim, Ciprofloxacin increases the ciliary transportability of the sputum of COPD patients, foram medidos os efeitos do ambroxol e da ciprofloxacina no transporte ciliar de muco de oito pacientes com DPOC, que apresentavam expectoração diária. Eles foram acompanhados por 36 dias consecutivos, com ingesta diária de ambroxol do dia 1 ao dia 8 e de ciprofloxacina, do dia 28 ao dia 36. O s autores avaliaram o transporte ciliar no palato de sapos e em traquéia bovina e analisaram em três fases, classificadas em imediata, crônica e booster. 0 ambroxol não apresentou nenhum efeito sobre o transporte ciliar, tanto no palato de sapos, quanto na traquéia de bois; contudo, a ciprofloxacina promoveu aumento significativo no transporte ciliar nos dois modelos preconizados. 0 uso de antibióticos tem sido controverso na DPOC. Saint e col.(15) realizaram uma metanálise de nove trabalhos randomizados utilizando pacientes com DPOC e aferição do pico de fluxo (PF). Verificou-se que o uso de antibiótico melhorava o PF 
significativamente mais que o uso de placebo. A redução da viscosidade do muco pode melhorar a sintomatologia do paciente com DPOC. O uso prolongado de antibiótico não tem impedido as descompensações, porém, pode ser considerado em cursos intermitentes quando o paciente apresentar mais de quatro infecções por ano ${ }^{(16)}$. A ciprofloxacina já é preconizada para pacientes DPOC infectados; no entanto, seus benefícios parecem que não se limitam somente a sua atividade bactericida, como foi demonstrado por este trabaIho.

O trabalho de Sachs e J ardim, Obesity and food pattern of el derly outpatients with chronic obstructive pulmonary disease, teve como objetivo caracterizar o estado nutricional, através do índice de massa corpórea (IMC), o modelo alimentar em homens com DPOC e detectar a presença de obesidade. 0 resultado demonstrou que $30 \%$ dos pacientes estavam com sobrepeso e somente $10 \%$ eram desnutridos. A nalisando apenas os pacientes com DPOC leve ou grave, $35,3 \%$ apresentavam sobrepeso. Foi verificada, também, uma mudança do hábito alimentar após o diagnóstico da doença, com a diminuição da ingesta de feijão, pão, café com açúcar, bebidas destiladas e gordura animal. A DPOC em estágio avançado está relacionada com a caquexia, que pode estar, por sua vez, associada a vários fatores, como idade avançada, diminuição do exercício, aumento do metabolismo, inflamação constante das vias aéreas e ao uso de drogas (corticosteróides). A redução da massa magra tem sido referida como "sarcopenia". Esta redução está associada à diminuição da força muscular estática e dinâmica e à atrofia das fibras musculares tipo II. A perda da massa e a da força muscular são conseqüência da própria idade ${ }^{(17)}$. Contudo, idosos com atividade física diária quando comparados com idosos sedentários apresentam diminuição da força e da massa muscular. Pesquisadores, utilizando treinamento de alta intensidade em idosos, demonstraram o aumento da força e da massa muscular. Deste modo, a atividade física é um fator de regulação da síntese protéica ${ }^{(18)}$. 0 estado de hipermetabolismo presente na DPOC tem sido atribuído ao aumento da trabalho respiratório, mas o emagrecimento não está uniformemente relacionado com o hipermetabolismo. A associação de caquexia e DPOC está diretamente relacionada com a mortalidade e, em algumas trabalhos, evidenciamos que até $50 \%$ dos pacientes que necessitam de internação estão desnutridos. A obesidade (IMC maior que 20) nos pacientes DPOC ainda tem recebido pouca atenção, apesar de Donahoe e col. ${ }^{(19)}$ relatarem uma incidência alta desta associação, semelhante à deste artigo, 37,2\%. 0 excesso de peso compromete to do o equilíbrio do sistema respiratório e, desta forma, deve ser evitado. Este estudo ressalta a importância da equipe multidisciplinar no acompanhamento dos pacientes com DPOC.

0 estudo de Velloso, Siva e J ardim, Pulmonary Disease (COPD) and normal subjects, teve como objetivo avaliar a demanda metabólica e ventilatória durante quatro atividades que envolviam exercício com os membros superiores. Dois grupos foram feitos, 9 pacientes de DPOC e 10 de pessoas consideradas saudáveis, realizaram quatro atividades físicas em dois dias diferentes, respirando sob máscara. Quatro parâmetros foram conseguidos: $\mathrm{VO}_{2}$ (captação de oxigênio), $\mathrm{VCO}_{2}$ (produção de dióxido de carbono), $\mathrm{V}_{\mathrm{E}}$ (ventilação-minuto) e FC (freqüência cardíaca). Nos dois grupos houve aumento significativo de todos os dados estudados. Concluindo que atividades físicas diárias, consideradas neste trabalho, justificariam o cansaço relatado nos DPOC de moderada a acentuada gravidade no seu dia-a-dia e que a relação $V_{E} /$ VVM (ventilação voluntária máxima) apresenta valores elevados, o que acarretaria a maior percepção de dispnéia. Os programas de reabilitação pulmonar para pacientes DPOC tipicamente enfatizam treinamento das extremidades inferiores (caminhadas). Muitos pacientes com DPOC referem dispnéia com atividades físicas consideradas "leves", como a troca de lâmpadas, que efetivamente são trabalhos menores que os dos membros superiores. Todavia, o exercício do membro superior é acompanhado de alta demanda ventilatória, para um nível de trabalho, quando comparado com o trabalho do membro inferior ${ }^{(20,21)}$. 0 estudo proposto por Velloso e col. confirma outros trabalhos relatados, obrigando à reflexão e, também, alertando para a necessidade de modificação da amplitude do trabalho físico multidisciplinar, com treinamento inclusive dos membros superiores, nos pacientes de DPOC.

Os breves comentários realizados sobre os resumos dos trabalhos provenientes do Brasil, que foram expostos no Congresso da ATS, têm a finalidade de mostrar aos pneumologistas a magnitude e a profundidade da investigação clínica e experimental já existentes no nosso país. Esta nova realidade da pesquisa brasileira, com a apresentação de oito trabaIhos somente na área de DPOC no congresso norte-americano (talvez seja o congresso de maior repercussão mundial na área de pneumologia), demonstra 0 avanço científico alcançado, apesar das inúmeras dificuldades e preconceitos ainda existentes por aqui. Todavia, o que felizmente se verifica é a atuação da nossa pesquisa abrangendo vários pontos da fisiopatologia e do tratamento da DPOC. A etapa que compõe a fase inicial da investigação clínica já há muito tempo foi conseguida; isto fica bem evidente com esses trabaIhos acima. Esperamos, para breve e com ansiedade, a publicação minuciosa desses estudos, para podermos compreender melhor todo o universo da DPOC.

\section{RefERÊNCIAS}

1. ATS standards for the diagnosis and care of patients with chronic obstructive pulmonary disease. Am J Respir C rit Care Med 1995;152(Suppl):S78-S121.

2. Higgins MW, Thom T. Incidence, prevalence, and mortality: Intra- and intercountry differences. In: Henseley MJ, Saunders NA, eds. Clinical epidemiology of chronic obstructive pulmonary disease. $1^{\text {st }}$ ed. New York: Marcel Dek ker, 1990;23-43. 
3. Belman M, B rooks I, Ross D, et al. Variability of breathlessness measurement in patients with COPD. Chest 1991;8:566-571.

4. Elliot MW, Mulvey DA, Moxhalm J, et al. Domiciliary nocturnal nasal intermittent positive pressure ventilation in COPD: mechanisms underlying changes in arterial blood gas tensions. Eur Resp J 1991;4:1044-1052.

5. Strumpf DA, Millman RP, Carlisle CC, et al. Nocturnal positive-pressure ventilation via nasal mask in patients with severe chronic obstructive pulmonary disease. Am Rev Respir Dis 1991;144:1234-1239.

6. Lin CC. Comparison between nocturnal nasal positive pressure ventilation combined with oxygen therapy and oxygen monotherapy in patients with severe COPD. Am J Respir Crit Care Med 1996;154:353-358.

7. Muir J F, C urvalier A, Tengang $B$, et al. Long-term home nasal intermittent positive ventilation (NIPPV) + oxygenotherapy (LTOT) alone in severe hypercapnic COPD. Preliminary results of a European multicentre trial. Am J Respir Crit Care Med 1997;155:A408.

8. Medical Research Council Working Party. Long-term domiciliary oxygen therapy in chronic hypoxic cor pulmonale complicating chronic bronchitis and emphysema. Lancet 1981;1:681-686.

9. Nocturnal Oxygen Therapy Trial Group. Continuous or nocturnal oxygen therapy in hypoxemic chronic obstructive lung disease. A clinical trial. Ann Intern Med 1980;93:391-398.

10. Dean NC, Brown J K, Himelman RB, et al. Oxygen may improve dyspnea and endurance in patients with chronic obstructive pulmonary disease and only mild hypoxemia. Am Rev Respir Dis 1992;146:941-945.

11. Tirlapur VG, Mir MA. Nocturnal hypoxemia and associated electrocardiographic changes in patients with chronic obstructive pulmonary disease. $\mathrm{N}$ Engl J Med 1982;306:125-130.

12. Heaton RK, Grant I, McSweeny AJ, et al. Psychologic effects of continuous and nocturnal oxygen therapy in hypoxemic chronic obstructive pulmonary disease. Arch Intern Med 1983;143:1941-1947.

13. Allred EN, Bleecker ER, Chaitman BR, et al. Short-term effects of carbon monoxide exposure on the exercise performance of subjects with coronary artery disease. N Engl J Med 1989;321:1426-1432.

14. McLean A, Lamb D, Gould G, et al. Morphometric factors causing airflow limitation in early chronic obstructive airways disease. Thorax 1987;39:44 49.

15. Saint $S$, Bent $S$, Vittinghoff $E$, et al. A ntibiotics in chronic obstructive pulmo nary disease exacerbations: a meta-analysis. J AMA 1995;273:957-960

16. Murphy TF, Sethi S. Bacterial infection in chronic obstructive pulmonary disease. Am Rev Respir Dis 1992;320:1521-1525.

17. Evans W, Campbell W. Sarcopenia and age-related changes in body composition and functional capacity. J Nutr 1993;54:1353-1360.

18. Frontera W, Meredith C, O'Reilly K, et al. Strength conditioning in older men. Skeletal muscle hypertrophy and improved function. J Appl Physio 1988;64:1038-1044

19. Donahoe M, Rogers RM, Wilson DO, et al. Oxygen consumption of the respiratory muscles in normal and malnourished patients with chronic obstructive pulmonary disease. Am Rev Respir Dis 1989;140:385-391.

20. Celli BR, Rassulo J, Make BJ . Dissynchronous breathing during arm but not leg exercise in patients with chronic airflow obstruction. N Engl J Med 1986; 314:1485-1491.

21. Ries AL. Pulmonary rehabilitation: evidence-based guidelines. ACCP/ AACVPR Pulmonary rehabilitation guidelines panel. Chest 1997;112:1363 1379.

RELIABILITY OF DYSPNEA SCALES IN THE ASSESSMENT OF LITERATE AND ILLITERATE PATIENTS WITH CHRONIC OBSTRUCTIVE PULMONARY DISEASE (COPD).

Martinez J AB, Straccia L, Sobrani E, Silva GA, Gomes U, Terra Filho J . Pulmonary Division, Faculty of Medicine of Ribeirão Preto, Universidade of São Paulo, SP, Brazil.

Objective: various scales have been used to record the degree of dyspnea, however none reported evaluating dyspnea in illiterate patients. As illiteracy still is a significant problem in developing countries, this study aimed to evaluate the reliability of 4 dyspnea scales in literate $(\mathrm{L})$ and illiterate $(\mathrm{IL})$ patients with COPD. Methods: we have stud- ied 87 COPD patients submitted to spirometry in our pulmonary function laboratory. After a standard explanation, patients were asked to score their breathless in the previous week, using a visual analogic scale (VAS), a numerical rating scale (NRS), the Borg scale, and the basal dyspnea index (BDI-Mahler). Each scale was presented to patients twice, before and after they had performed the proceedings related to the spirometry. Results: according to Unicef criteria, $30 \mathrm{pa}-$ tients (34\%) were classified as IL and 57 as L. Both groups had similar age and degree of respiratory impairment $\left(\mathrm{VEF}_{1}: \mathrm{IL}=45 \pm 24 \% \mathrm{XL}=\right.$ $43 \pm 21 \%$ ). There was no difference in the degree of dyspnea between groups by any of the 4 scales. There was high degree of correlation between scores obtained before and after spirometry for all scales (VAS: II $r=0.95 \times$ L $r=0.95$; NRS: IL $r=1,00 \times$ L $r=0.98$; Borg: $\| r=$ $1,00 \times L r=1.00 ; B D I: \| r=0.99 \times L r=0.99$ ). The best correlations between pulmonary function tests and degree of dyspnea were obtained using BDI. Conclusion: COPD patients IL and L show the same degree of reliability in response to dyspnea scales. BDI is also a useful tool to evaluate dyspnea in IL subjects.

EFFECTS OF CONTINUOUS POSITIVE AIRWAY PRESSURE IN PULMONARY REHABILITATION IN PATIENTS WITH CHRONIC OBSTRUCTIVE PULMONARY DISEASE.

O liveira IM, Reis MAS, Andrade AD, Rodrigues-Machado MG. Faculdade de Ciências Médicas of MG, Prontocor Hospital, Brazil.

The administration of continuous positive airway pressure (CPAC) during spontaneous breathing in patients with chronic obstructive pulmonary disease (COPD) decreases work of breathing and dyspnea. Objective: to verify the effects of CPAP $\left(5 \mathrm{cmH}_{2} \mathrm{O}\right)$ associated with conventional pulmonary rehabilitation (CRP) in patients with COPD. Methods: eight patients $(69.75 \pm 9.77$ years old $)$ with COPD were randomly assigned to CPR group $(n=4)$ and CPR associated to CPAP (CPR + CPAP group) $(n=4)$, during cycle ergometer exercise. Effects of CPAP were assessed through spirometry, six-minute walk test, maximal inspiratory pressure (Pimax) and dyspnea (Borg scale), after 36 sessions during 12 weeks. Results: a significant improvement was observed in RPC + CPAP group $(p<0.05)$ at forced vital capacity $(1.77$ $\pm 0.36 \mathrm{~L}$ to $2.08 \pm 0.28 \mathrm{~L}$ ) and medial walk distance $(76.62 \pm 12.58 \%$ compared with initial test), and reduction in dyspnea (Borg scale 15.75 \pm 2.99 to $12.00 \pm 1.16$ ). PI max increased significantly in both groups. Conclusion: CPAP improved significantly endurance probably by reducing exertional dyspnea.

ASSOCIATION BETWEEN AIR POLLUTION AND CARDIOVASCU LAR ADMISSIONS IN SÃO PAULO, BRAZIL.

Lin CA, Braga ALF, Conceição GMS, Pereira LAA, Kishi HS, Milani J r. R, Saldiva PHN. Laboratory of Experimental Air Pollution, School of Medicine, University of São Paulo, SP, Brazil.

This work focuses the relation between air pollution and hospital admissions due to ischemic cardiovascular illness (angina and acute heart infarction-ICI) in São Paulo City. Daily records of hospital admissions for people between 45 and 80 years were obtained from the Heart Institute of the University of São Paulo Medical School, from J anuary 1994 to December 1995. Daily measures of CO, SO, $\mathrm{PM}_{10}$ and Ozone were obtained for the same period from the State Air Pollution Controlling Agency (C etesb) as well as weather variables obtained from Institute of Astronomy and Geophysics of the University of São Paulo. The analysis was made by Poisson regression techniques, controlled of time trend, weather and days of week. CO (2-days moving average) was the pollutant that exhibited the most robust association with cardiovascular admissions. The average levels of $\mathrm{CO}$ during the study $(5.2 \mathrm{ppm})$ were associated with $6 \%$ increase of $\mathrm{ICI}$. This association exhibited a linear behavior and did not disclose any evi- 
dence of safety threshold. The results of this study support the idea that air pollution promotes significant health effects in São Paulo.

LONG-TERM OXYGEN THERAPY-PROSPECTIVE 2-YEAR STUDY USING GUIDELINES ADAPTED TO BRAZILIAN PUBLIC HEALTH SYSTEM REALITY: POPULATION, CHARACTERISTICS, BENEFITS AND MORTALITY RATE.

Machado MCLO, Lemos GHP, Oliveira RHR, Santos SRR, Silva CR, Pereira CAC. Respiratory Division of the State Public Hospital of São Paulo, SP, Brazil.

Long-term domiciliary oxygen therapy (LTOT) has been prescribed for clinic hypoxemia and its benefits are unequivocal. Hypoxemic patients enrolled at the Respiratory Division of the State Public Hospital of São Paulo have been receiving at home compressed-gas cylinders for LTOT. According to international recommendations, and in order to better study and supervise that population, we have designed our own guidelines, adapted to Brazilian Public $\mathrm{H}$ ealth System reality and was applied from Oct/ 96 through 0 ct/ 98 in 129 stable outpatients, and it is summarized below.

\begin{tabular}{|c|c|c|c|}
\hline Character & Initial values & Character & Initial values \\
\hline$n$ & 129 & Age* & $69 \pm 9$ years \\
\hline Diagnosis* & $\begin{array}{l}\text { COPD }=70 \% \\
\text { Pulm. fibrosis }=18 \% \\
\text { Others }=12 \%\end{array}$ & Race* & $\begin{array}{l}\text { Caucasian }=90 \% \\
\text { Africans }=9 \% \\
\text { Asians }=1 \%\end{array}$ \\
\hline Gender* & M. $56 \% / F .44 \%$ & $\begin{array}{l}02 \text { hours } \\
\text { prescriptions* }\end{array}$ & $16 \pm 3 \mathrm{hs} /$ day \\
\hline $\mathrm{FEV}_{1}^{*}$ & $1.05 \pm 0.6 \mathrm{~L}$ & $\mathrm{SaO}_{2}$ (rest)* & $85 \% \pm 6 \%$ \\
\hline $\mathrm{PaO}_{2}$ (rest)* & $54.4 \pm 10.9 \mathrm{mmHg}$ & Previous smoking* & $74 \% / 50 \pm 28$ pack/years \\
\hline Pulm. HTN & Present in $80 \%$ & $\mathrm{Htc} / \mathrm{Hb}^{*}$ & $60 \% \pm 3 \% / 17.4 \pm 2.0 \mathrm{~g}$ \\
\hline Mortality rate & $\begin{array}{l}20 \% / 2 \text {-year } \\
\text { surveillance }\end{array}$ & $\begin{array}{l}\text { Freq. of } \\
\text { hospitalization*/a year }\end{array}$ & $\begin{array}{l}\text { Before/after LTOT } \\
4 \text { times/1 time }\end{array}$ \\
\hline
\end{tabular}

* Average \pm Standard deviation. HTN = hypertension.

The profile studied is of 70 -year old male COPD patient, Caucasian, $\mathrm{PaO}_{2}=55 \mathrm{mmH} \mathrm{g}, \mathrm{FEV}_{1}=1.0 \mathrm{~L}$, pulmonary hypertension, exsmoking $(50 \mathrm{p} / \mathrm{y})$. The benefits were the reduction in the frequency of hospitalization and the decrease in the mortality rate.

ANALYSIS OF METABOLIC AND VENTILATORY PARAMETERS DURING THE ACTIVITIES OF DAILY LIVING (ADL) IN PATIENTS WITH CHRONIC OBSTRUCTIVE PULMONARY DISEASE (COPD) AND NORMAL SUBJECTS.

Velloso M, Siva AC, J ardim S. Pulmonary Rehabilitation Center, Respiratory Division and Physiology Department, Universidade Federal de São Paulo, Brazil.

Aim: the upper limbs are largely involved in human daily activities (ADL). Normal subjects usually perform such activities without noticing its energy cost but COPD patients report tiredness when performing them. This study was designed to assess the metabolic and ventilatory demands in COPD patients during the performance of four activities involving upper limbs. Methods: ten male normal subjects $(N)$ younger than COPD patients ( 27.9 years) (to test the reproducibility of the methods proposed) and nine male COPD patients entered the study. They were tested in two different days breathing in a mask; oxygen uptake $\left(\mathrm{VO}_{2}\right)$, carbon dioxide output $\left(\mathrm{VCO}_{2}\right)$, minute ventilation (VE) and heart rate $(H R)$ were measured while performing $A D L$ for 5 minutes; sweeping the floor, cleaning a blackboard, lifting plastic pots and replacing lamps. The 2 tests were reproducible and $\mathrm{VO}_{2}, \mathrm{VCO}_{2}, \mathrm{VE}$ and $H R$ increased $(p<0.05)$ for both groups.

\begin{tabular}{|c|c|c|c|c|c|c|c|c|c|c|}
\hline \multirow[t]{2}{*}{ Activities } & \multicolumn{2}{|c|}{ Baseline } & \multicolumn{2}{|c|}{$\begin{array}{l}\text { Sweeping } \\
\text { floor }\end{array}$} & \multicolumn{2}{|c|}{$\begin{array}{c}\text { Cleaning } \\
\text { blackboard }\end{array}$} & \multicolumn{2}{|c|}{$\begin{array}{l}\text { Lifting } \\
\text { pots }\end{array}$} & \multicolumn{2}{|c|}{$\begin{array}{c}\text { Replacing } \\
\text { lamps }\end{array}$} \\
\hline & $\mathrm{N}$ & COPD & $\mathrm{N}$ & COPD & $\mathrm{N}$ & COPD & $\mathrm{N}$ & COPD & $\mathrm{N}$ & COPD \\
\hline $\mathrm{VO}_{2} \mathrm{NO}_{2 \max }(\%)$ & 13 & 36 & 19 & 55 & 16 & 48 & 20 & 58 & 16 & 45 \\
\hline VE/MVV $(\%)$ & 7 & 40 & 10 & 57 & 9 & 55 & 11 & 63 & 9 & 55 \\
\hline $\mathrm{HR} / \mathrm{HR}_{\max }(\%)$ & 46 & 56 & 51 & 63 & 52 & 63 & 54 & 67 & 52 & 65 \\
\hline
\end{tabular}

Conclusion: we conclude that moderate to severe CPOD patients when performing these four tested activities present a high oxygen uptake, what may explain the tiredness reported by them during simple activities, involving the upper limbs. Their VE/ VVM is high, what leads them to a high level of perceived dyspnea. The heart rate kept an average value over $60 \%$ of their maximal predicted; this heart rate may probably decreased by a specific exercise program in pulmonary rehabilitation.

\section{SF-36 QUALITY OF LIFE IMPROVES FOLLOWING PULMONARY} REHABILITATION IN COPD PATIENTS.

Boueri FMV, Bucher-Bartelson B, Glenn K, Make B.

The purpose of this study was to evaluate the effects of a 3-week comprehensive pulmonary rehabilitation program on quality of life as measured by the SF-36 in patients with COPD. We report on the outcomes of 37 consecutive patients referred for pulmonary rehabilitation at a respiratory specialty medical center. Rehabilitation consisted of 12 exercise sessions, each of which included bicycle ergometer exercise training, upper extremity training, strength training, and stretching, psychosocial counselling and education. Baseline evaluation included spirometry, and patients completed the SF-36 and performed a 6 minute walk test before and after rehabilitation. There was an improvement in 5 of the 9 quality of life subscales of the SF-36 following pulmonary rehabilitation. Although there was an improvement in functional capacity as measured by the 6 -minute walk, there was no correlation between improvement in quality of life and improvement in functional capacity. Although there was no correlation between $\mathrm{FEV}_{1}$ and improvement in walk distance, there was a correlation between $\mathrm{FEV}_{1}$ and improvement in SF-36 physical function and energy/ fatigue subscales. We conclude that the SF-36, a general measure of quality of life, can be used to assess changes in HQL following pulmonary rehabilitation.

THE CILIARY TRANSPORTATION OF THE SPUTUM OF COPD PATIENTS IS SLOW BOTH ON THE FROG PALATE AND ON THE BOVINE TRACHEA.

Oliveira J CA, Gastaldi A, Jardim JR. Federal University of J uiz de Fora, São Paulo Centro Universitário do Triângulo, Brazil.

Ciliary transportability is the ability of mucus to be transported by the cilia. The most used method to study the ciliary transportability is the mucus-depleted frog palate. A new method studying the ciliary transportability of the mucus on the bovine trachea has been described and implied that it could make different previsions from those seen in the frog palate. We assessed the ciliary transportability of the sputum of eight stable COPD patients with daily expectoration on the frog palate and on the bovine trachea. The assessments were made on five different occasions during a time interval of 63 days. The results have shown that the ciliary transportability of the sputum of COPD patients is slow both on the frog palate and on the bovine trachea. The transportability was expressed as an index, the relative transport velocity. Then we considered all the samples this way, 0.71 on the frog palate compared to 1.2 in individuals without lung disease. On the bovine trachea the relative transport velocity was 0.18 compared to 0.74 without lung disease. We have also seen that the coefficient of variation 
was bigger in the trachea than in the frog palate, respectively 0.33 and 0.91. We concluded: i) that the two models used to assess the ciliary transportability made previsions in the same directions, ii) that the ciliary transportability of the sputum of COPD patients is slow both on the frog palate and on the bovine trachea, iii) that the frog palate has shown a smaller variability than the bovine trachea as a method to assess the ciliary transportability of COPD patients.

CIPROFLOXACIN INCREASES THE CILIARY TRANSPORTABILITY OF THE SPUTUM OF COPD PATIENTS.

O liveira J CA, Saldiva PH, J ardim J R. Federal University of J uiz de Fora and São Paulo, Universidade de São Paulo, Brazil.

Ambroxol is a drug that is largely employed to improve secretion clearance in COPD patients albeit controversies regarding a real effect of this drug. Recently it was described that antibiotics could improve the mucus ciliary transportability. The most used method to study the ciliary transportability is the mucus-depleted frog palate. A new method studying the ciliary transportability of the mucus on the bovine trachea has been described and implied that it could make different previsions from those seen in the frog palate. We assessed the effects of ambroxol and ciprofloxacin on the ciliary transportability of the sputum of eight COPD patients with daily expectoration. They were followed up for 36 consecutive days. They received ambroxol one $30 \mathrm{mg}$ tablet tid from day one to day eight and ciprofloxacin one $250 \mathrm{mg}$ table from day 28 to 36 . The interval of time between the two drugs was permitted to wash out the effects of the firts drug. We collected sputum at 8 and 11 a.m. on the days that the drugs were started and finished. We have studied the drug effect on the ciliary transportability of the sputum on three times to evaluate what we have called immediate, chronic and booster effect of the drug. The ciliary transportability was measured on the frog palate and on the bovine trachea. A mbroxol has shown no effect upon the ciliary transportability both on the frog palate and on the bovine trachea. Ciprofloxacin has induced a statistically significant increase in the ciliary transportability both in the frog palate $(p=0.058$ and 0.02$)$ and in the bovine trachea $(p=0.01)$ when we studied the immediate and booster effects. We concluded: i) that the two models used to assess the ciliary transportability made previsions in the same direction, ii) that ambroxol did not modify the ciliary transportability of the sputum of COPD patients, iii) that ciprofloxacin determined a strong increase in sputum ciliary transportability of COPD patients.

OBESITY AND FOOD PATTERN OF ELDERLY OUTPATIENTS WITH CHRONIC OBSTRUCTIVE PULMONARY DISEASE (COPD).

Sachs A, J ardim J R. U niversidade Federal de São Paulo/ Escola Paulista de Medicina - Preventive Medicine, Nutrition Division, Respiratory Division, São Paulo, Brazil.

Aim: to characterize nutritional status and food pattern of COPD patients, to detect the presence of obesity and its relation to morbidity and mortality. 60 ambulatory elderly males with different degrees of COPD (ATS) starting a rehabilitation program were evaluated. Methods: body mass index (BMI) and the cut-off points recommended by the World Health Organization (1995) were used to assess the nutritional status. Food pattern was obtained from the quantitative food frequency method. Results: $43.3 \%$ were classified as moderate COPD; $10 \%$ of all patients as undernourished, $60 \%$ as having normal weight and $30 \%$ as overweight, $35.3 \%$ of those with mild and severe COPD were overweight. These data are contrary to what has been mentioned by the literature, that usually shows higher proportion of malnutrition among COPD patients and about $3 \%$ of obesity. The overweight status found does not represent an increased risk for morbi-mortality in this group as no patient showed BMI above $30.8 \mathrm{~kg} / \mathrm{m}^{2}$. Comparing the present food pattern of the overweight patients with the period prior to the diagnosis of the disease, it was observed an increase in the number of patients using fruit juices, rice, bread, chicken, milk and soft drinks and a decrease in the daily consumption of beans, beef, coffee with sugar, alcoholic beverages and animal fat. The mean calorie intake was $2390 \pm 725 \mathrm{kcal}$ (1562-3682). This value is very close to their daily energy requirements. The distribution of protein, fat and carbohydrate in relation to the total calorie intake was $14.7 \% \pm 2.4$ $(10-20), 30.7 \% \pm 6.8(19-41)$ and $54.7 \%$ (42-64), respectively, showing that they have a balanced diet. 